\title{
The role of the registered nurse in the marketing of primary healthcare services, as part of health promotion
}

\author{
M Rail, MCur \\ Department of Nursing Sciences, Faculty of Health Sciences, University of Pretoria \\ SM Meyer, PhD \\ Department of Nursing Sciences, Faculty of Health Sciences, University of Pretoria
}

\section{Keywords:}

Primary health care, marketing, health promotion, role of nurses

\section{Abstract: Curationis 29(1): 10-24}

Existing literature on the marketing of primary healthcare services was reviewed to determine the role of registered nurses in this regard. The systematic review included five searches and ensured wide coverage of the results of available primary research studies on the topic. The results were summarised and the role of registered nurses in the marketing of primary healthcare services was identified. Primary research sources on the topic included textbooks on marketing by experts in the field and relevant journal articles by authorities on healthcare marketing. The data were analysed and four main categories identified. To ensure the trustworthiness of the research, Lincoln and Guba's (1981:215-216) criteria, as explained by Krefting (1991:217), were applied. Because the population consisted of only literature, ethical considerations concerning human subjects were irrelevant. Results indicated that the basic commercial marketing principles (the so-called 4Ps - product, price, place, and promotion) could be adapted for the health sector. The conclusion was that registered nurses could contribute to the marketing of primary healthcare services by communicating with the community (promotion) and by ensuring effective service (product) delivery at the right price and place. Registered nurses could influence the community's perceptions of health care and facilitate behaviour changes, thereby promote health. The implementation of the findings and recommendations of this research could create a new awareness among registered nurses of their role in the marketing of primary healthcare services in South Africa and improve their skills in this regard.

\section{Opsomming}

Bestaande literatuur oor die bemarking van primêre gesondheidsorgdienste is krities beoordeel om die rol van die geregistreerde verpleegkundige in hierdie verband te bepaal. Die sistematiese kritiese beskouing het vyf literatuursoektogte behels en wye dekking van die resultate van beskikbare primêre navorsingstudies oor die onderwerp verseker. Die resultate is opgesom en die rol van geregistreerde verpleegkundiges in die bemarking van primêre gesondheidsorgdienste bepaal. Primêre navorsingsbronne oor die onderwerp het handboeke oor bemarking deur kundiges in die veld en aktuele wetenskaplike tydskrifartikels deur gesaghebbendes oor gesondheidsorgbemarking ingesluit. Die data is geanaliseer en vier hoofkategorieë geïdentifiseer. Om die betroubaarheid van die navorsing te verseker, is Lincoln en Guba (1981:215-16) se kriteria, soos deur Krefting (1991:217) bespreek, toegepas. Aangesien die populasie slegs uit literatuur bestaan het, was etiese oorwegings, wat ten opsigte van menslike subjekte geld, irrelevant. Die resultate het aangedui dat die basiese kommersiëlebemarkingsbeginsels (die sogenaamde 4P's - produk, prys, plek en promosie) vir die gesondheidsektor aangepas kon word. Die gevolgtrekking was dat geregistreerde verpleegkundiges kan meewerk aan die bemarking van primêre 
gesondheidsorgdienste deur met die gemeenskap te kommunikeer (promosie) en te verseker dat ' $n$ effektiewe diens (produk) teen die regte prys en op die regte plek gelewer word. Die geregistreerde verpleegkundige kan ook die gemeenskap se persepsies van gesondheidsorg beïnloed, gedragsveranderinge fasiliteer en op dié wyse gesondheid bevorder. Die implementering van die bevindinge en aanbevelings van hierdie navorsing kan geregistreerde verpleegkundiges opnuut bewus maak van hulle rol in die bemarking van primêre gesondheidsorgdienste in Suid-Afrika en hulle vaardighede in hierdie verband verbeter.

\section{Introduction}

A literature review was conducted to determine the role of registered nurses in the marketing of primary healthcare services, as part of health promotion. The research design and methodology, the interpretation of the data, and the recommendations made, will be discussed.

\section{Problem statement}

Following the statement by the African National Congress that every individual has the right to achieve optimal health (ANC 1994), the mission statement issued by the South African Department of Health becomes clear: "To provide leadership and guidance to the NHS (National Health System) in its efforts to promote and monitor the health of all people in South Africa; and to provide caring and effective services through the primary healthcare approach" (Dennill, King \& Swanepoel 1999:170).

However, if primary healthcare services are unavailable or inaccessible to the community, inter alia due to lack of knowledge, optimal health cannot be achieved. Marketing of healthcare services is a relatively new concept in the non-profit healthcare industry. As the emphasis is not on profit making, but on service delivery, marketing of primary healthcare services is seen as an uphill task. The extent of the involvement of the community health nurse/registered nurse in the marketing of services should not be underestimated. If communities were not informed about primary healthcare services, in other words, if these services were not marketed, accessibility, equity and availability could not be ensured.

\section{Aim of the research}

By reviewing literature on the topic, the researcher aimed to determine the role of registered nurses in the marketing of primary healthcare services.

\section{Research question}

To achieve this aim, the following research question was formulated: What role does registered nurses play in the marketing of primary healthcare services as part of health promotion?

The research objectives were formulated as sub-questions:

- What is the registered nurse's role in the marketing of primary healthcare services?

- How can the registered nurse use marketing to promote health?

- What should be in place to enable the registered nurse to deliver health services?

- How can the registered nurse reach the external environment?

\section{Relevance of the research}

Uncertainty exists about the role of the registered nurse in the marketing of primary healthcare services. Through marketing, healthcare services can be made more available and accessible to the community, and health be promoted.

The systematic review of available evidence on the role of nurses in the marketing of primary healthcare services provided answers to the research question. The synthesised data can assist decision-making on the delivery of health care and the planning of new primary research.

\section{Research design and methodology}

Qualitative research was conducted by applying systematic review methods. According to the Center for Reviews and Disseminations (CRD Publications Office 2001), a systematic review is a review of evidence on clearly formulated questions. Systematic and explicit methods are used to identify, select and critically appraise relevant primary research, and to extract and analyse data from the studies included in the review. The results of unmanageable quantities of research can be summarised and duplication of research avoided.

Systematic reviews differ from traditional reviews and commentaries produced by content experts in that they use a replicable, scientific and transparent approach that minimises bias. Rather than reflecting the views of experts, they generate balanced inferences based on a collation of information and an analysis of available evidence (CRD Publications Office 2001). Following completion of the review, relevant research data are summarised and inferences drawn.

\section{Population and sampling}

A systematic literature review is based on a preliminary assessment of potentially relevant literature. Scoping searches, including searches for existing reviews and primary studies relevant to the objectives of the research, are carried out (CRD Publications Office 2001). These searches are most effective when aided by experts in information retrieval. To ensure wide coverage, a range of sources has to be consulted. The CRD Publications Office (2001) suggests that searches of databases and web resources be supplemented with searches made by key research groups in the field.

A good review should focus on welldefined questions and the methodology be geared toward obtaining valid answers. In this research, the reviewer was determined to search for all literature relevant to the research question. Criteria for selecting or rejecting studies have to be determined. All literature included in the research should directly address the research question.

For this study, thirty-four journal articles were gathered from the Medline database. Six textbooks on marketing, written by experts in the field, were selected and used. The relatively small sample of relevant literature enabled the researcher to focus on the research topic.

\section{Data analysis}

According to De Vos, Strydom, Fouche, Poggenpoel, Schurink and Schurink (1998:337), there is no right or wrong approach to performing data analysis. However, the researcher should be able to logically account for all stages of the data analysis. The conclusion should be based on the generated data.

An adapted version of Tesch's (1990:1546) model for qualitative data analysis, as described by Creswell (1994:154-6), was used for this study. The researcher tried to make sense of the whole by reading 
through the journal articles and textbooks and by writing down ideas as they came to mind. These steps were taken to determine the underlying meaning of the data.

Four main categories emerged from the data obtained, namely:
1. The purpose of marketing primary healthcare services;
2. The plan of action;
3. Making these services available; and
4. The realisation of external/ community ownership.

The categories were colour coded. The researcher returned to the articles and textbooks and colour coded the appropriate text segments. After separating the different segments, data belonging to each category were assembled in one place. To ensure data accessibility, as suggested by Schurink (1996:3-12), different files were created the master file contained the original raw data and the analytical files the data on the categories. The study report was structured according to the sets of data organised into the analytical files.

\section{Trustworthiness}

Reviews should be assessed and critically appraised for quality. Quality can be defined as confidence that bias is minimised by the design, conduct and analysis of the review (CRD Publications Office 2001). Quality assessment is important because the effectiveness of interventions may be masked or exaggerated by reviews that are not rigorously conducted.

The process whereby study relevance and quality are assessed, should be unbiased, reproducible and transparent. If this process is not well documented, confidence in the results of a review is weakened. The review should clearly display the results of all studies included, highlight any similarities or differences and explore the reasons for variations. In light of these results, and considering the population, interventions and outcomes covered by the review, it should be possible to make a judgment about the applicability and value of the review's findings (CRD Publications Office 2001).

Lincoln and Guba's (1981:215-16) criteria for assessing trustworthiness, as discussed by Krefting (1991:217), were used to ensure a quality review. These criteria are as follows:

\section{- $\quad$ Truth value/Credibility:}

Confidence in the truth of the data was established by making use of multiple references, a technique known as data source triangulation.

- Applicability/Transferability:

Using articles published in acclaimed journals and researching the role of the registered nurse in the context of national health systems improved the possibility of fitting findings/results into contexts outside this study situation.

\section{Confirmability:}

In qualitative studies, confirmability does not focus on the characteristics of the researcher (is s/he objective and unbiased?), but rather focuses on the characteristics of the data (is the data confirmable?). An inquiry audit can be used to establish both dependability and confirmability of data (Polit \& Hungler 1997:307).

An up-to-date, published, systematic review of good quality can be used to guide healthcare decisions. However, it is possible to update or extend a published review of reasonable quality to generate the information required (CRD Publications Office 2001).

\section{Ethical considerations}

The population for this research consisted of journal articles, reviews, and textbook data. Human beings were not used as subjects; therefore, ethical considerations, such as selfdetermination, privacy, anonymity, confidentiality, protection from harm, and informed consent, were irrelevant.

\section{Limitations of the study}

Only one database, Medline, was used for the retrieval of information. As more databases would have produced more data, this could be seen as a limitation of the study. However, this was a study of limited scope, and the limitation ought not to have had a significant effect on results. A further limitation was the number of South African sources found. Most data were retrieved from internationally acclaimed journals.

\section{Literature search strategy}

The aim of the literature search was to generate a comprehensive list of primary studies on the research topic that could be used for answering the research question. The strategy for identifying relevant studies has to be thorough and unbiased, because the validity of findings is directly related to the comprehensiveness of the search. Moreover, the level of precision in the effect estimate that can be generated by a systematic review depends upon the volume of information included in the review. It is important to be aware of the range of potential biases and to use a variety of search methods (both computerised and manual) to ensure a comprehensive search (CRD Publications Office 2001). For the purposes of this study, five searches were conducted.

\section{Search 1}

Information on marketing that was discussed as part of a master's course in community health nursing, as well as journal articles on marketing of health services found on the Internet in June 2002, was set aside for future reference. The eighteen articles found on the Medline database are summarised in Table 1 .

Relevant articles from accredited journals were screened for arguments on:

The importance of marketing
health services;
The purpose of marketing
primary healthcare services;
Marketing tools and strategies
to reach the external
environment;
Utilities to satisfy health needs;
and
A plan of action to promote
health through marketing.

Accredited journals, such as Marketing Health Services, Journal of Advanced Nursing, Nursing Standards and The American Journal of Public Health, contained relevant articles by experts in the fields of marketing and public, primary, and community health care. Authors were selected because of their interest and authority in the study fields mentioned. Table 2 displays the authority of authors of articles found during searches 2 and 3 .

\section{Search 2}

Constructing an effective combination of search terms for an electronic database search requires a structured approach. One such approach involves breaking down the research question into facets, such as population, interventions, outcome and study design. With respect 
Table 2: Searches 2 and 3: Information on authors

\begin{tabular}{|c|c|c|}
\hline AUTHOR & FIELDOFAUTHORITY & INSTITUTION \\
\hline Collinson, S. & Not indicated. & Not indicated. \\
\hline Cowley, S. & $\begin{array}{l}\text { Professor of Nursing: Practice } \\
\text { development and evaluation. }\end{array}$ & King's College, London. \\
\hline McDermott, B. & Consumer services manager. & $\begin{array}{l}\text { Northern Health and Social Services } \\
\text { Board, Ballymera. }\end{array}$ \\
\hline Sohail, A. & International population services. & $\begin{array}{l}\text { Department of Demography, University } \\
\text { of Zambia, Lusaka. }\end{array}$ \\
\hline Whitehead, D. & Senior lecturer. & $\begin{array}{l}\text { Institute of Health Studies, University } \\
\text { of Plymouth, UK. }\end{array}$ \\
\hline Baxter-Derrington, $\mathrm{P}$. & Facilitator, marketing communications. & Health Care First Ltd, Surrey, England. \\
\hline Reuter, L. & Associate Professor. & $\begin{array}{l}\text { Faculty of Nursing, University of Alberta, } \\
\text { Canada. }\end{array}$ \\
\hline Ford, JS. & Associate Professor. & $\begin{array}{l}\text { Faculty of Nursing, University of Alberta, } \\
\text { Canada. }\end{array}$ \\
\hline Livesey, $\mathrm{H}$. & Senior lecturer and practitioner. & $\begin{array}{l}\text { University of Central Lancashire and } \\
\text { Guild Community NHS Trust, Preston, } \\
\text { England. }\end{array}$ \\
\hline Calpin-Davis, $\mathrm{P}$. & Senior nursing lecturer. & $\begin{array}{l}\text { School of Nursing and Midwifery, } \\
\text { University of Sheffield, UK. }\end{array}$ \\
\hline Carole, D. & Registered nurse, PhD student. & King's College, London. \\
\hline Russel, S. & $\begin{array}{l}\text { Principal researcher - Health and illness } \\
\text { issues. }\end{array}$ & Nortcote, Victoria, Australia. \\
\hline Daly, J. & Associate Professor. & $\begin{array}{l}\text { Palliative Care Unit, University of } \\
\text { Australia. }\end{array}$ \\
\hline Hughes, E \& Hoog, C. & Research officers. & $\begin{array}{l}\text { Palliative Care Unit, University of } \\
\text { Australia. }\end{array}$ \\
\hline Vucki, A. & Assistant Professor. & $\begin{array}{l}\text { School of Nursing, Dalhousie University, } \\
\text { Canada. }\end{array}$ \\
\hline Keddy, B. & Professor. & $\begin{array}{l}\text { School of Nursing, Dalhousie University, } \\
\text { Canada. }\end{array}$ \\
\hline Mullan, F. & Not indicated. & $\begin{array}{l}\text { Department of Prevention and } \\
\text { Community Health, George Washington } \\
\text { University of Public Health, Washington } \\
\text { DC, USA. }\end{array}$ \\
\hline Epstein, L. & Not indicated. & $\begin{array}{l}\text { Department of Social Medicine, Hebrew } \\
\text { University. Hadassah Brown School of } \\
\text { Public Health and Community Medicine, } \\
\text { Jerusalem. }\end{array}$ \\
\hline Rosen, R \& Mountford, L. & Both specialists. & $\begin{array}{l}\text { Registrars in public health. The King's } \\
\text { Fund, London, UK. }\end{array}$ \\
\hline
\end{tabular}




\begin{tabular}{|c|c|c|}
\hline JOURNAL ARTICLETTTIE & AUTHOR/S \& NAME OF JOURNAL & AUTHORITY OF AUTHORS \\
\hline $\begin{array}{l}\text { Realizing your marketing influence. Part } \\
1 \text { - Meeting patients' needs through } \\
\text { collaboration. }\end{array}$ & $\begin{array}{l}\text { Woods, DK. 2002. Journal of Nursing } \\
\text { Administration. 32(4): } 189-95 \text {. }\end{array}$ & $\begin{array}{l}\text { American Association of Critical Care } \\
\text { Nurses (AACN). }\end{array}$ \\
\hline $\begin{array}{l}\text { Realizing your marketing influence. Part } \\
2 \text { - Marketing from the inside out. }\end{array}$ & $\begin{array}{l}\text { Woods. DK \& Cardin. S. 2002. Journal of } \\
\text { Nursing Administration. 32(6):232-330. }\end{array}$ & $\begin{array}{l}\text { Woods: AACN } \\
\text { Cardin: Assistant Professor, UCLA } \\
\text { School of Nursing, Los Angeles. }\end{array}$ \\
\hline $\begin{array}{l}\text { Marketing strategy: An essential } \\
\text { component of business development for } \\
\text { academic health centers. }\end{array}$ & $\begin{array}{l}\text { Souba, WW, Haluck, CA \& Menezes, } \\
\text { MAJ. 2001. The American Journal of } \\
\text { Surgerv. } 181(2): 105-14 .\end{array}$ & $\begin{array}{l}\text { Souba: Department of Surgery, Penn } \\
\text { State College of Medicine, USA. } \\
\text { Haluck: Department of Strategic } \\
\text { Services, Penn State College of } \\
\text { Medicine, USA. } \\
\text { Menezes: Marketing Department, } \\
\text { Boston University School of } \\
\text { Management, USA. }\end{array}$ \\
\hline $\begin{array}{l}\text { Marketing: A nursing leadership } \\
\text { imperative. }\end{array}$ & $\begin{array}{l}\text { Byers, JF. 2001. Nursing Economics. } \\
19(3): 94-9 .\end{array}$ & $\begin{array}{l}\text { Associate Professor, University of } \\
\text { Central Florida, Orlando. }\end{array}$ \\
\hline Twenty years of health care marketing. & $\begin{array}{l}\text { Beckham. D. } 2001 \text {. Health Forum Journal. } \\
\text { 44(4):37-40. }\end{array}$ & $\begin{array}{l}\text { President of the Beckham Company. } \\
\text { American Marketing Association } \\
\text { (AMA). }\end{array}$ \\
\hline Building on first impressions. & $\begin{array}{l}\text { Thomas, RK. 2002. Marketing Health } \\
\text { Services. 22(2):34-8. }\end{array}$ & AMA. \\
\hline Welcome to experience economy. & $\begin{array}{l}\text { Iacobucci, D, Calder, BJ, Malthouse, E \& } \\
\text { Duhachek. A. 2002. Marketing Health } \\
\text { Services. 22(2):16-20. }\end{array}$ & $\begin{array}{l}\text { Iacobucci: Professor of Marketing. } \\
\text { University of Arizona. } \\
\text { Calder: Professor of Marketing. } \\
\text { Northwestern University. } \\
\text { Malthouse: Assistant Professor. } \\
\text { Northwestern University. } \\
\text { Duhachek: Doctoral student, } \\
\text { Northwestern University. }\end{array}$ \\
\hline $\begin{array}{l}\text { Developing community capacity and } \\
\text { improving health in African-American } \\
\text { communities. }\end{array}$ & $\begin{array}{l}\text { Raczynski, JM, Cornell, CE, Stalker, } \\
\text { VMPA, Philips, M, Dignan, M, Pulley, L } \\
\text { \& Leviton. L. 2001. The American Journal } \\
\text { of Medical Science. } 322(5): 294-300 .\end{array}$ & $\begin{array}{l}\text { Center of Health Promotion, Department } \\
\text { of Health, Division of Preventive } \\
\text { Medicine, University of Alabama, } \\
\text { Birmingham. }\end{array}$ \\
\hline Ethical challenges of social marketing. & $\begin{array}{l}\text { Brenkert. R. 2002. Journal of Public Policy } \\
\text { and Marketing. 21(1):14-25. }\end{array}$ & $\begin{array}{l}\text { Professor of Business Ethics, } \\
\text { McDonough School of Business, } \\
\text { Georgetown University. }\end{array}$ \\
\hline $\begin{array}{l}\text { Medical compliance and health care } \\
\text { marketing. }\end{array}$ & $\begin{array}{l}\text { Halpern. NJL \& Grymes. SP. 2002. Medical } \\
\text { Marketing and Media. 37(5):88-98. }\end{array}$ & $\begin{array}{l}\text { Both attorneys, Law firm of Olsson, } \\
\text { Washington DC. }\end{array}$ \\
\hline Welcome to the experience economy. & $\begin{array}{l}\text { Pine. II \& Gilmore. JH. } 2001 \text {. Health Forum } \\
\text { Joumal. 44(5):10-6. }\end{array}$ & $\begin{array}{l}\text { Both founders of Strategic Horizons LLP } \\
\text { of Aurora, Ohio. }\end{array}$ \\
\hline
\end{tabular}

to each facet, search terms are identified that capture the subject best. The groups of search terms should include a range of text words that occurs in the titles and abstracts of primary studies, as well as database subject indexes. Text words and their variants are identified when reviews and primary studies obtained during earlier searches are read (CRD Publications Office 2001). Using the search terms 'marketing health' and 'social marketing', five articles were found during a Medline database search in September 2003. These articles are summarised in Table 3. 


\begin{tabular}{|c|c|c|}
\hline $\begin{array}{l}\text { AUTHOR/S AND YEAR OF } \\
\text { PUBLISHING }\end{array}$ & JOURNALARTICLETTTLE & NAME OF JOURNAL \\
\hline Collinson, S \& Cowley, S. 1998. & $\begin{array}{l}\text { An explanatory study of demand for the } \\
\text { health visiting service within a marketing } \\
\text { framework. }\end{array}$ & $\begin{array}{l}\text { Journal of Advanced Nursing. 28(3), } \\
\text { September: 499-507. }\end{array}$ \\
\hline McDermott, B. 1996. & Marketing nursing. & $\begin{array}{l}\text { Nursing Standards. 10(20). February: } 49- \\
56 .\end{array}$ \\
\hline Sohail, A. 2001. & $\begin{array}{l}\text { Intention to use the female condom } \\
\text { following a mass-marketing campaign in } \\
\text { Lusaka, Zambia. }\end{array}$ & $\begin{array}{l}\text { American Journal of Public Health. 91(2). } \\
\text { February: 307-10. }\end{array}$ \\
\hline Whitehead, D. 2000. & $\begin{array}{l}\text { Using mass media within health } \\
\text { promoting practice: A nursing } \\
\text { perspective. }\end{array}$ & $\begin{array}{l}\text { Journal of Advanced Nursing. 32(4). } \\
\text { October: 807-16. }\end{array}$ \\
\hline Weiss, R. 2002. & Tales from the market front. & Marketing Health Services. 22(2):12-3. \\
\hline
\end{tabular}

\section{Search 3}

Using the search terms 'health marketing', 'health promotion', 'nursing roles', 'how to market health services' and 'patient satisfaction', a second Medline database search was conducted. After reading the abstracts to determine usability, eleven articles were selected. A summary of the selected articles is included as Table 4 .

\section{Search 4}

Applying the search term 'marketing of health', data about relevant textbooks were retrieved from UP Explorer, the browser for the Intranet of the University of Pretoria. Textbooks used for previous studies also proved to be useful, as they contained information on the topic of this research. The textbooks used and the authors' fields of interest are listed in Table 5.

\section{Search 5}

An additional, manual search was conducted to find sources to assist in the formulation of the research design and methodology, as well as the analysis of data. These sources are summarised in Table 6.

\section{Conclusions and recommendations}

The views of authors/experts on commercial and social marketing were analysed and categorised. Conclusions were drawn about: $\bullet$

The role of the registered nurse in the marketing of healthcare services;

- Using social marketing to promote health;

- $\quad$ Making primary healthcare services available through marketing; and

- Reaching the external environment.

\section{The role of the registered nurse in the marketing of healthcare services}

The South African national healthcare plan is based on the belief that every individual has the right to achieve optimal health. If primary healthcare services were available, affordable, effective and accessible, the community would be aware of these services. Thus, as part of health promotion, the registered nurse has to assist in the marketing of primary healthcare services.

To ensure equal access to quality health care, the South African government has to create, monitor and, if necessary, change the framework or system of healthcare delivery (Dennill et al.1999:42). Changes to healthcare delivery planned in 1994 were aimed at the decentralisation of services, with the emphasis on primary healthcare delivery and community care. The proposed system allowed for a continuum of health care, with a referral system that would permit easy, logical movement between primary, secondary and tertiary services. If the structure for delivering these services were in place, the registered nurse could assist in promoting primary healthcare services.

\section{Conclusions}

When the key concepts of this study were clarified, it became clear that different authors had a mutual understanding of the concept 'marketing' (Refer to Table 7). Although this concept was developed in the commercial sector, it can extend to different types of service (McDermott 1996).

Many people equate marketing with sales and promotion. This, however, is a wrong approach, as marketing refers to a broad discipline, of which sales and promotion is but one subset. Most authors stated that, by marketing, organisations can determine customers' wants or needs, and develop and offer goods or services.

Since marketing is about identifying and satisfying people's needs, healthcare needs ought to be assessed before primary healthcare services are marketed. According to Collinson and Cowley (1998:501), determining human needs is considered the starting point. The needs assessment process is also called 'marketing research' (Kotler, Roberto \& Lee 2002:7). Various needs classification systems exist. Compare the types of need (Perreault \& McCarthy 2002:158) with the categories of needs (Dennill et al. 1999:154) as set out in Table 8. 


\begin{tabular}{|c|c|c|}
\hline $\begin{array}{l}\text { AUTHOR/S AND YEAR OF } \\
\text { PUBLISHING }\end{array}$ & JOURNALARTICLETITLE & NAME OF JOURNAL \\
\hline Baxter-Derrington, P. 1995. & Marketing: Getting your message across. & Nursing Standards. 9(41), July: 20-3. \\
\hline Reuter, L \& Ford, JS. 1996. & $\begin{array}{l}\text { Perceptions of public health nursing: } \\
\text { Views from the field. }\end{array}$ & $\begin{array}{l}\text { Journal of Advanced Nursing. 24( 1), July: } \\
7-15 \text {. }\end{array}$ \\
\hline Livesey, H. 1998. & $\begin{array}{l}\text { Fund-holding and contracting for } \\
\text { community nursing services: A selective } \\
\text { review of the literature. }\end{array}$ & $\begin{array}{l}\text { Journal of Advanced Nursing. } 28(3) \text {, } \\
\text { September: 483-90. }\end{array}$ \\
\hline Calpin-Davis, P. 1998. & $\begin{array}{l}\text { A comprehensive business planning } \\
\text { approach applied to healthcare. }\end{array}$ & Nursing Standards. 12(46), August: 35-41. \\
\hline Carole, D. 2003. & $\begin{array}{l}\text { Modernisation: The role of ward sisters } \\
\text { and charge nurses. }\end{array}$ & Nursing Standards. 17(52). September: 33 - \\
\hline $\begin{array}{l}\text { Russel, S, Daly, J, Hughes, E \& Hoog, C. } \\
2003 .\end{array}$ & $\begin{array}{l}\text { Nurses and difficult patients: Negotiating } \\
\text { non-compliance. }\end{array}$ & $\begin{array}{l}\text { Journal of Advanced Nursing. } 43(3) \text {. } \\
\text { August: } 281-7 .\end{array}$ \\
\hline Vucki, A \& Keddy, B. 2002. & $\begin{array}{l}\text { Northern nursing practice in a primary } \\
\text { health care setting. }\end{array}$ & $\begin{array}{l}\text { Journal of Advanced Nursing, } 40(5) \text {, } \\
\text { December: } 542-8 .\end{array}$ \\
\hline Morgan, IS \& Marsh, GW. 1998. & $\begin{array}{l}\text { Historic and future health promotion } \\
\text { context for nursing. }\end{array}$ & $\begin{array}{l}\text { Journal of Nursing Scholarship. 30(4): } 379 \text { - } \\
83 .\end{array}$ \\
\hline Mullan, F \& Epstein, L. 2002. & $\begin{array}{l}\text { Community oriented primary care: New } \\
\text { relevance in a changing world. }\end{array}$ & $\begin{array}{l}\text { American Journal of Public Health. 92(11), } \\
\text { November: } 1748-55 .\end{array}$ \\
\hline Rosen, R \& Mountford, L. 2002. & $\begin{array}{l}\text { Developing and supporting extended } \\
\text { nursing roles: The challenges of NHS } \\
\text { walk-in centers. }\end{array}$ & $\begin{array}{l}\text { Journal of Advanced Nursing. 39(3). } \\
\text { August: } 241-8 .\end{array}$ \\
\hline
\end{tabular}

The registered nurse has to identify the target group's specific needs. This will ensure that the customer purchases the health product/service. A relationship of trust between registered nurses and customers will facilitate the process of needs assessment.

According to Weiss $(2002: 12,13)$, advertising drives marketing. This, however, is a myth that persists. Advertising helps to increase visibility, awareness, understanding and positioning in health care. Relationships though, drive results. A relationship of trust between the registered nurse and the customer will help create a supportive climate in which the customer will experience a sense of security (Dennill $e t$ al. 1999:146). In a climate of trust and support, the registered nurse will be considered the most reliable source of health-related information. Such a relationship will enable the nurse to facilitate adjustments, such as the development of behaviour that promotes health.

\section{Recommendations}

- $\quad$ Registered nurses should take responsibility for co-coordinating clinical and marketing departments by sharing their knowledge on healthcare services and their understanding of patients' needs.

- $\quad$ Registered nurses should not be bound by traditional roles. They should be made aware that they have a vital role to play in marketing research, trust building, and the utilisation of primary healthcare services.

- $\quad$ The emphasis should be placed on public relations. Registered nurses should know that advertising does not drive marketing and that a big budget is not needed.
Data gathering and analytical tools can improve the healthcare provider's ability to identify needs and modify existing services. These tools, as well as communication skills, can be acquired by attending inservice training sessions and workshops.

- Patient evaluation forms and a suggestion box are simple ways to acquire community input. Feedback will tell whether plans are working, and managing plans often means modifying marketing strategies (Perreault \& McCarthy 2002:53). Kotler et al. (2002:73) are quoting Faith Popcorn when they state: "If you want to know what customers want, ask. That's the foundation of customer research ... The trick, of course, is knowing what 


\begin{tabular}{|c|c|}
\hline TEXTBOOKS' AUTHOR/S & EXPERTISEANDFIELDOFINTEREST \\
\hline $\begin{array}{l}\text { Kotler, P, Roberto, N \& Lee, N. } 2002 . \\
\text { Social marketing: Improving the } \\
\text { quality of life. } 2^{\text {nd }} \text { edition. London: } \\
\text { Sage. }\end{array}$ & $\begin{array}{l}\text { Kotler: Author of various books on marketing. Expert on marketing of non-profit } \\
\text { organisations and social marketing. Published over } 100 \text { research articles in leading journals. } \\
\text { Received various AMA awards. } \\
\text { Roberto: Coca-Cola Foundation. Professor in international marketing. Interests include } \\
\text { basic marketing, social marketing and consumer behaviour. Author of seven books. } \\
\text { Published several articles in international journals. } \\
\text { Lee: Expert in social marketing. Held numerous corporate marketing positions. Consulted } \\
\text { with more than } 100 \text { non-profit organisations. Participated in development of more than } 50 \\
\text { social marketing campaign strategies for public sector agencies. Active in AMA. }\end{array}$ \\
\hline $\begin{array}{l}\text { Dennill, K, King, L\& Swanepoel,T. } \\
\text { 1999. Aspects of primary health } \\
\text { care: Community health care in } \\
\text { Southern Africa. } 2^{\text {nd }} \text { edition. Cape } \\
\text { Town: Oxford University Press. }\end{array}$ & $\begin{array}{l}\text { These authors lectured in community health nursing at the University of South Africa } \\
\text { (UNISA), Pretoria. }\end{array}$ \\
\hline $\begin{array}{l}\text { Dreyer, M, Hattingh, } S \& \text { Lock, } M \text {. } \\
\text { 1997. Fundamental aspects of } \\
\text { community nursing. } 2^{\text {nd }} \text { edition. } \\
\text { Halfway House: Thomson } \\
\text { Publishing. }\end{array}$ & $\begin{array}{l}\text { These authors were lecturers in the then Department of Advanced Nursing Sciences at } \\
\text { UNISA (now the Department of Health Studies). }\end{array}$ \\
\hline $\begin{array}{l}\text { Dienemann, AJ. 1998. Nursing } \\
\text { administration: Managing patient } \\
\text { care. } 2^{\text {nd }} \text { edition. USA: Appleton \& } \\
\text { Lange. }\end{array}$ & $\begin{array}{l}\text { Associate Professor and Coordinator: Nursing Systems and Management, School of } \\
\text { Nursing, The John Hopkins University, Baltimore, Maryland. }\end{array}$ \\
\hline $\begin{array}{l}\text { Perreault, WD \& McCarthy, EJ. } \\
\text { 2002. Basic marketing: A global } \\
\text { managerial approach. New York: } \\
\text { McGraw-Hill. }\end{array}$ & $\begin{array}{l}\text { Perreault: Recipient of AMA Distinguished Educator Award and Academy of Marketing } \\
\text { Science Outstanding Educator Award. Great impact on marketing research. Previous editor } \\
\text { of Journal of Marketing Research. Past president of AMA. } \\
\text { McCarthy: Voted one of the 'top five' leaders in marketing; thought highly of by marketing } \\
\text { educators. Wrote various articles and some text books on marketing. }\end{array}$ \\
\hline $\begin{array}{l}\text { Van Rensburg, HCJ, Fourie, A \& } \\
\text { Pretorius, E. } 1992 . \\
\text { Gesondheidsorg in Suid-Afrika: } \\
\text { Struktuur en dinamika. Pretoria: } \\
\text { Van Schaik. }\end{array}$ & $\begin{array}{l}\text { Van Rensburg: Head of the Department of Sociology at the University of the Free State } \\
\text { (UFS), Bloemfontein, South Africa. } \\
\text { Fourie: Lecturer and researcher in the Department of Sociology, UFS. Focuses on the } \\
\text { reconstruction of the South African health system. } \\
\text { Pretorius: Lecturer in the Department of Sociology, UFS. }\end{array}$ \\
\hline
\end{tabular}

questions to ask and knowing how to listen to the answer."

\section{Using social marketing to promote health \\ Conclusions}

Conclusions were drawn about registered nurses' involvement in social marketing and health promotion.

\section{- $\quad$ Social marketing}

The research also focused on the role that registered nurses could play in a plan of action to facilitate adjustments and promote healthy lifestyles. Hillestad and
Berkowitz (1991:18), as well as Perreault and McCarthy (2002:14), stated that marketing facilitates the voluntary exchange of items. In a non-profit primary healthcare clinic, services are rendered free of charge, but the expectation is that customers will voluntarily change their behaviour to improve their health. Refer to the definitions of social marketing set out in Table 9.

Andreason (1995:8), as well as Kotler $\boldsymbol{e t}$ al. (2002:5), supports the principle that customers, in exchange for services, voluntarily change behaviour. Motivation, perceptions, learning attitudes and lifestyle needs are basic forces that motivate a person to change behaviour. A customer may look at a market/service offering from two perspectives: one deals with the potential benefits of that offering and the other is concerned with what the customer has to pay to get those benefits (Perreault \& McCarthy 2002:160). Because customers will consider both the benefits of primary healthcare services and the sacrifices/behaviour changes they have to make, registered nurses have to focus on the benefits of those services for the customer (called 'customer value' by Perreault and McCarthy (2002:38)). 


\begin{tabular}{|c|c|}
\hline AUTHORS \& YEAR OF PUBLISHING & TIIUE \\
\hline $\begin{array}{l}\text { De Vos, AS, Strydom, H, Fouche, DB, Poggenpoel, M, Schurink, } \\
\text { E \& Shurink, W. } 1998 .\end{array}$ & Research at grass roots: A primer for the caring professions. \\
\hline Schurink, W. 1996. & Paper on qualitative data analysis. \\
\hline Hillestad, SG \& Berkowitz, EN. 1991. & Health care marketing plans - From strategy to action. \\
\hline Polit. DF \& Hungler, BP. 1997. & $\begin{array}{l}\text { Essentials of nursing research: Methods, appraisal and } \\
\text { utilization. }\end{array}$ \\
\hline McLauglin. CP \& Kaluzny, AD. 1994. & Continuous quality improvement in health care. \\
\hline Andreason, AR. 1995. & $\begin{array}{l}\text { Marketing social change: Changing behaviour to promote } \\
\text { health, social development and the environment. }\end{array}$ \\
\hline Creswell, JW. 1994. & Research design. Qualitative and quantitative approaches. \\
\hline
\end{tabular}

Ethical considerations should also be kept in mind. Crossing ethical borders of respect and professionalism will alienate the community, and lead to noncompliance and negative attitudes toward behavioural change. Changing behaviour may involve modifying attitudes, values and norms (Brenkert 2002). By keeping the customer's social context and cultural background in mind, the registered nurse will be able to offer health information that is relevant and useful.

According to Perreault and McCarthy (2002:42), as well as Pine and Gilmore (2001:13), customers will reject a service/ product if they see one feature as substandard. Because a positive attitude will promote compliance, participation and the health of the customer, registered nurses should encourage such an attitude toward primary healthcare services and behavioural change.

\section{- Health promotion}

Americans are moving away from the idea that health is the absence of disease and the result of medical intervention. They are accepting a broader definition, which includes both personal responsibility and quality of life, with self-care and prevention as key words. Individuals are taking a more pro-active approach to health care, seeking information and adjusting lifestyles to improve their health. This self-care trend affords nurses the opportunities to act as sources of referral. Nurses can also guide people to optimise their health by managing personal health risks (Dienemann 1998: 187). This point of view is echoed by Van Wyk (1999:31) who states that health promotion enables individuals to take control of their own life/well-being. Healthy public policies and health education empower people to take responsibility for their own health.

By making informed decisions about their health and by changing behaviour, informed people know they can improve their health. Healthy public policies can create a climate that is conducive to decision-making in this regard. Health education, also a component of health promotion, will be enhanced if a supportive environment were established by means of healthy public policies (Norton 1998:1271).

\section{Recommendations}

- To change the traditional paradigm, where advice and information are given to the patient (one-way communication), registered nurses/ healthcare providers have to become facilitators of health. They need to work in partnership with the consumer (two-way communication).

- $\quad$ Registered nurses have to change their attitudes toward patients. Instead of labelling them as non-compliant, nurses should assume responsibility and transfer knowledge about health matters to the patient, thereby facilitating decisionmaking.

- $\quad$ Through proper patient assessment, registered nurses have to try and solve causing factors of illness, rather than treat symptoms. Registered nurses are not in a position to change the circumstances of a patient, but they can empower the community by making them aware of their capacity to effect change.

- $\quad$ Registered nurses have to be sensitive to the social context, as well as the cultural background, of the communities they serve. Compliance may improve if they gain the respect of the community.

- $\quad$ Through marketing, available primary healthcare services can be brought to the attention of the community. Knowledge boosts confidence, and confident communities may access these services and make informed decisions

- $\quad$ To change the perceptions of the community about healthcare services and encourage regular visits, services have to exceed expectations. Registered nurses have to ensure that services meet the community's needs. Aspects such as friendliness, respect, flexible clinic times and a proper referral 


\begin{tabular}{|l|l|}
\hline AUTHORS & MUTUAL UNDERSTANDING OF THE CONCEPT'MARKETING' \\
\hline Hillestad and Berkowitz(1991:28) & Determining customers' wants and needs. \\
\hline Perreault and McCarthy (2002:4) & More than selling and advertising. Identifying customers' needs. \\
\hline Collinson and Cowley (1998:499-507) & Identifying and satisfying customers' needs. \\
\hline McDermott (1996:49-56) & Anticipating and fulfilling customers' needs. \\
\hline Baxter-Derrington(1995:20-3) & Anticipating and satisfying customers' wants, needs and demands. \\
\hline
\end{tabular}

system will enhance acceptance among community members.

Registered nurses should be more involved in policy making, because they could act as advocates for the community.

\section{Making primary healthcare services available through marketing \\ Conclusions}

The most fundamental principle of marketing is marketing research. The marketer has to understand what the target audience knows, believes and does. Marketing research begins with an analysis of the potential needs, wants, beliefs, problems, concerns and behaviours of the different market segments. Marketers then select the target markets they can affect and satisfy best (Kotler et al. 2002:7). Clear goals and objectives concerning the marketing of available services have to be established.

Four major tools in the marketer's toolbox, also referred to as the marketing mix, are used to influence the target market. These are; product, price, promotion and place, the so-called 4Ps. Such a marketing mix can be used to reach the important goal of delivering primary healthcare services that are available, accessible, affordable, effective, equitable, and efficient.

To achieve these objectives (availability, affordability etc.), certain strategies or requirements have to be implemented. A comparison between these strategies/ requirements, as discussed by Dennill et al. (1999:6) and Van Rensburg, Fourie and Pretorius (1992:364), is displayed in Table 10. To ensure the successful delivery of primary healthcare services, registered nurses have to strive to reach these objectives (Dennill et al. 1999:6).

The traditional 4Ps (product, price, place, promotion), as described in the commercial market, are not directly applicable to the social market, although fundamental tenets hold firm. To make the marketing mix more appropriate to health services, the 4Ps were converted to service (product), cost (price), delivery (place) and communication mix (promotion) by Baxter-Derrington (1995:22). Similarities that exist between the commercial market and the social market made this conversion possible. The traditional 4Ps, as well as the adapted 4'P's and the corresponding primary healthcare objectives, are presented in Table 11 .

According to Perreault and McCarthy (2002:248), the product/service refers to the market offering that would satisfy a specific need. The focus should be on the customer and the customer's needs. Services should also be congruent with the customer's values and desires. This will make the service acceptable to the customer.

Price/cost is what the customer has to give up to receive the benefit (Perreault \& McCarthy 2002:484). In a non-profit health organisation, it is not money, but rather the customer's ability to pay a price that will promote health. This may include, for example, an investment of time, energy, and motivation.

Brenkert (2002:18) describes this as a 'welfare exchange'. Because price/cost can be a barrier to the utilisation of primary healthcare services, it is important to make sure that services are affordable and customers receive value in exchange for investments.
Place/delivery is concerned with all the decisions that are involved in getting the right product to the target audience (Perreault \& McCarthy 2002:48). Services should be extended to be accessible to all people (Dennill et al. 1999:6). Services should be available and convenient, and accommodate clients' needs. The therapeutic process will be enhanced by a warm, caring physical environment, which will also attract more customers.

Through promotion/the communication mix, information about the offer is given to the target audience, who is inspired to act (Kotler et al. 2002:264). The target audience is informed about the right product that is delivered at the right price and place. The relation between the 4'P's and the primary healthcare objectives is summarised in Table 12.

While planning primary healthcare delivery, the mix of nurse attributes should also be considered. According to Livesey (1998:485), nursing skills and experience, as well as professional and social networks, are nurse attributes that form the foundation of a successful strategy for the implementation of health services. Calpin-Davis (1998:37) also explains that productivity improves efficiency and leads to successful healthcare delivery. Through excellence, compassion, social responsibility, and faith in themselves and others, registered nurses will be able to promote their services (Dana \& Woods 2002:325).

\section{Recommendations}

- $\quad$ Registered nurses should partake in the analysis of customers' wants and needs to be able to offer satisfactory services. 


\begin{tabular}{|c|c|}
\hline TYPES OF NEED (PERREAULT \& McCARTHY 2002:158) & CATEGORIES OF NEEDS(DENNILL et al. 1999:154) \\
\hline $\begin{array}{ll}\text { - } & \text { Physiological needs } \\
\text { - } & \text { Psychological needs } \\
\text { - } & \text { Desires } \\
& \text { Need for freedom }\end{array}$ & $\begin{array}{ll}- & \text { Needs felt } \\
\text { - } & \text { Needs expressed } \\
-\quad & \text { Normative needs } \\
\text { - } & \text { Comparative needs }\end{array}$ \\
\hline
\end{tabular}

Table 9: Definitions of social marketing (Kotler et al.; Andreason)

\begin{tabular}{|l|l|}
\hline KOTLER et al. (2002:5) & ANDREASON (1995:8) \\
\hline $\begin{array}{l}\text { Social marketing is the use of marketing principles and } \\
\text { techniques to influence a target audience to voluntarily accept, } \\
\text { reject, modify or abandon behaviour for the benefit of } \\
\text { individuals, groups or society as a whole. }\end{array}$ & $\begin{array}{l}\text { Social marketing is the 25-year-old discipline that applies the } \\
\text { marketing technologies developed in the commercial sector } \\
\text { to the solution of social problems, for which the bottom line is } \\
\text { promoting behavioural change. }\end{array}$ \\
\hline
\end{tabular}

If registered nurses were customer orientated, the marketing mix (4'P's) could be applied to influence the target market.

To present the marketing mix to the community in an acceptable manner, the following should be in place:

Service: Health services have to be effective and need orientated, as customers seek to gain benefit from services offered to them. Cost and benefits: There should be a relation between the perceived cost and benefits. and this could lead to behavioural changes and health promotion.

\section{Reaching the external environment}

Incorporating the marketing mix into healthcare planning will improve the availability, affordability, equity, accessibility and efficiency of primary healthcare services. Offering the right product at the right price, at a convenient place, will lead to a 'welfare exchange' between the marketer and consumer. Promoting primary healthcare services may positively influence perceptions and increase the probability that the product will be 'purchased'. The first step is to inform the consumer about the availability of services. Consumers need information that can be seen, heard or held (Baxter-Derrington 1995:23).

\section{Conclusions}

Communication tools (such as the mass media, e.g. advertising, personal selling and public relations) are used to reach the external environment. These tools are vital to the successful marketing of health promotion products.

In a non-profit organisation, the budget for advertising, if any, would be very low and for this reason, media should be selected with discretion. The advantages and disadvantages of different media should be kept in mind (Refer to Table 13). Although the press, radio and television reach large audiences, they are expensive and lack selectivity. In the case of electronic media, the probability exists that the consumer can stop paying attention to the message (Hillestad \& Berkowitz 1991:80).

Seldom nurses are directly involved in the marketing of primary healthcare services. However, they should realise that they have a role to play in informing the community about these services. Registered nurses should attempt to design advertisements that would turn unawareness into awareness, and enthuse the community's interest in what is being offered (Baxter-Derrington 1995:23).

Personal attributes of registered nurses, such as friendliness, approachability and confidence, can almost instantaneously influence the health beliefs and behaviours of community members (Whitehead 2000:810).

Positive nurse attributes contribute toward good public relations, which will positively influence the community's attitude toward the services delivered and encourage community support (Dienemann 1998:200). No budget is needed when this route of promotion is followed, and by word of mouth the offering will be 'sold' by a satisfied community. 
Table 10: Strategies/requirements for the successful implementation of primary healthcare services

\begin{tabular}{|c|c|c|}
\hline OBJECTIVES & $\begin{array}{l}\text { STRATEGIESFORIMPLEMENTATION } \\
\text { (DENNILL et al. 1999:6) }\end{array}$ & $\begin{array}{l}\text { REQUIREMENTSFOR } \\
\text { IMPLEMENTATION(VAN } \\
\text { RENSBURG et al. 1992:364) }\end{array}$ \\
\hline Availability & $\begin{array}{l}\text { There should be sufficient and } \\
\text { appropriate services to meet the particular } \\
\text { health needs of each community. }\end{array}$ & $\begin{array}{l}\text { The geographical, strategic and logistical } \\
\text { distribution of preventative, curative and } \\
\text { rehabilitative services should benefit all. }\end{array}$ \\
\hline Affordability & $\begin{array}{l}\text { The level of health care offered should be } \\
\text { brought into alignment with the health } \\
\text { spending capacity of the community and } \\
\text { country. No person should be denied } \\
\text { health care because of an inability to pay. }\end{array}$ & $\begin{array}{l}\text { The price of health care should be in } \\
\text { alignment with the health spending } \\
\text { capacity of the community and no person } \\
\text { should be denied health care because of } \\
\text { an inability to pay. }\end{array}$ \\
\hline Effectiveness & $\begin{array}{l}\text { Services should provide the type of care } \\
\text { intended for a specific community. } \\
\text { Services rendered must be justifiable in } \\
\text { terms of total costs. }\end{array}$ & Not described. \\
\hline Efficiency & $\begin{array}{l}\text { In terms of effort, money, resources and } \\
\text { time, the results attained should be } \\
\text { appropriate to the input. }\end{array}$ & Not described. \\
\hline Accessibility & $\begin{array}{l}\text { Services must be within reach of all } \\
\text { people in the country. Special attention } \\
\text { should be given to previously } \\
\text { disadvantaged regions. Services should } \\
\text { be geographically, financially and } \\
\text { functionally accessible. }\end{array}$ & $\begin{array}{l}\text { Accessibility implies the abolishment of } \\
\text { geographical, financial, racial, political } \\
\text { and other obstacles to healthcare access. }\end{array}$ \\
\hline Equity & $\begin{array}{l}\text { All people should have equal access to } \\
\text { basic healthcare. There should be no } \\
\text { discrepancy in care. }\end{array}$ & Not described. \\
\hline Applicability and relevancy & Not described. & $\begin{array}{l}\text { There should be a relation between } \\
\text { services and facilities offered and the } \\
\text { needs of the community. }\end{array}$ \\
\hline Acceptability & Not described. & $\begin{array}{l}\text { Services should be personally and socio- } \\
\text { culturally acceptable to the community. } \\
\text { Their values and norms should be } \\
\text { respected. }\end{array}$ \\
\hline Adaptability & Not described. & $\begin{array}{l}\text { Regular evaluation of primary healthcare } \\
\text { services is necessary because of the } \\
\text { ever- changing health needs of the } \\
\text { community. }\end{array}$ \\
\hline
\end{tabular}

According to Collinson and Cowley (1998:502), the healthcare visitor's role can be conceptualised as a "bridge across the lay and professional spheres". The community tends to see the healthcare visitor as an expert, someone able to give advice and guidance. If service delivery/treatment is not explained, the appropriate use of the service may be adversely affected. The health visitor's interpersonal skills and ability to build relationships could lead to the community supporting healthcare services. Accepting consumers and showing sensitivity toward their health problems will encourage them to reveal their hidden needs.

According to Souba, Haluck and Menezes (2001:105), registered nurses should realise that patients judge health care not only by its technical quality (was the treatment successful?), but also by its functional quality (was the registered nurse caring/compassionate?).

Furthermore, registered nurses should realise that they are selling an experience, of which the environment is a part. Thomas (2002:35) states that the environment contributes to patient and employee satisfaction and, in this regard, serves as marketing tool. Appropriate designs (in terms of form and function) 
Table 11: The traditional 4p's (Commercial Market), the 4'p's (Health Sector) and the corresponding healthcare objectives

\begin{tabular}{|c|c|c|}
\hline $\begin{array}{l}\text { 4Ps: } \\
\text { COMMERCIALMARKET }\end{array}$ & $\begin{array}{c}\text { 4'P's: } \\
\text { HEALTHSECTOR }\end{array}$ & $\begin{array}{l}\text { PRIMARY HEAITHCARE } \\
\text { OBJECTIVES }\end{array}$ \\
\hline $\begin{array}{l}\text { Product: That which the } \\
\text { company wishes you to buy }\end{array}$ & $\begin{array}{l}\text { Service: That which the patient } \\
\text { seeks to benefit from. }\end{array}$ & Effectiveness, acceptability. \\
\hline $\begin{array}{l}\text { Price: What the customer pays } \\
\text { for the product. }\end{array}$ & $\begin{array}{l}\text { - Cost: Estimated in terms of cost/ } \\
\text { benefit, income/expenditure, } \\
\text { people, time and effort. }\end{array}$ & Affordability. \\
\hline $\begin{array}{l}\text { Place: The route the product } \\
\text { travels from the manufacturer to } \\
\text { the customer. }\end{array}$ & $\begin{array}{l}\text { - Delivery: Where, when and } \\
\text { how? }\end{array}$ & Availability, accessibility. \\
\hline $\begin{array}{l}\text { Promotion: Means by which the } \\
\text { company engages the } \\
\text { customer's desire to buy the } \\
\text { product. }\end{array}$ & $\begin{array}{l}\text { - Communication mix: Means by } \\
\text { which customers learn about } \\
\text { services and benefits. }\end{array}$ & Equity, efficiency. \\
\hline
\end{tabular}

Table 12: Summary of relation between the 4'p's (Health Sector) and the Primary Healthcare objectives

\begin{tabular}{|c|c|}
\hline 4'P's (HEALTH SECTOR) & OBJECTIVES \\
\hline - $\quad$ Service & - $\quad$ Effectiveness, Acceptability \\
\hline Cost & Affordability \\
\hline Delivery & - $\quad$ Availability, Accessibility \\
\hline - $\quad$ Communication mix & - $\quad$ Equity, Efficiency \\
\hline
\end{tabular}

contribute to the effectiveness of services provided, better outcomes, patient satisfaction and a progressive image of the organisation. A primary healthcare clinic that is well organised, renders quality care and expert advice, and operates within a functional environment, will market itself.

\section{Recommendations}

- $\quad$ Registered nurses should be familiar with communication tools. As opposed to other members of the multidisciplinary team, registered nurses are in regular contact with the community, and therefore in a position to influence behaviour and promote health.

- $\quad$ By using the media, registered nurses can update the community on health matters.
- $\quad$ Feedback from the community is important, to be able to modify advertising initiatives. The effectiveness of services can then be increased.

- The most cost-effective communication tool is personal selling. Registered nurses should exceed expectations by using their common sense and by being innovative and creative. When they sell an experience, services will be promoted by word of mouth.

\section{Final conclusion}

The aim of this research was to determine the role of the registered nurse in the marketing of primary healthcare services, as part of health promotion. By conducting a systematic review, it became clear that the basic commercial marketing principles are applicable to the social market, which includes the public health sector. Definite roles for registered nurses in the marketing of primary healthcare services were identified.

Current policies and practices regarding the marketing of primary healthcare services should be reconsidered in light of the evidence contained in this review. The ultimate aim is an improvement in the quality, availability and accessibility of primary healthcare services, and therefore health outcomes. This aim can be achieved if relevant research findings were appropriately incorporated into practice.

Information on the marketing of health services focuses on profit-seeking organisations and strategies used in this regard. The specific role of the registered nurse in the marketing of primary 


\begin{tabular}{|c|c|c|}
\hline MEDIASELECTION & ADVANTAGES & DISADVANTAGES \\
\hline Newspapers & - $\quad$ Coverage & - $\quad$ Lack of selectivity \\
\hline Magazines & Reach specific target & - Costly \\
\hline Direct mail & Selectivity & - $\quad$ Classification as junk mail \\
\hline Radio & $\begin{array}{ll}- & \text { Costs are relatively low } \\
\text { - } & \text { Some selectivity } \\
\text { - } & \text { Station assistance } \\
\text { Reaches large audience }\end{array}$ & $\begin{array}{l}\text { - } \quad \text { Listener does not pay attention } \\
\text { to the message }\end{array}$ \\
\hline Television & $\begin{array}{l}\text { - } \\
\text { - }\end{array}$ & - $\quad$ Costly \\
\hline Outdoor advertising & $\begin{array}{l}\text { Supplementing other } \\
\text { advertisements }\end{array}$ & - $\quad$ Little selectivity \\
\hline Computer/Internet & $\begin{array}{ll}- & \text { Interaction } \\
- & \text { Engages consumer }\end{array}$ & Costly \\
\hline
\end{tabular}

healthcare services is described only vaguely. This research was necessary to determine the specific roles of registered nurses in this regard. Kotler et al. (2002:111) quote Eckhort who states: "What we plant in the soil of contemplation we shall reap in the harvest of action."

\section{Suggestions for further research}

To ensure that the findings of this systematic review are applicable to the South African context, further research is recommended. The following suggestions are made:

- As this research is based on data obtained from international sources, the topic could be further researched, using South African sources.

- Increasing the sample size and retrieving information from several databases could broaden the scope of the research.

- $\quad$ Further research on the topic could include the design of a complete marketing plan. McDermott (1996:51) states that a comprehensive marketing approach is needed to meet all needs.

- $\quad$ Research could be conducted to determine whether the primary healthcare structure, planned in 1994, were in place and whether this structure allowed for the participation of registered nurses in the marketing of services.

- The extent of the involvement of registered nurses in the marketing and planning of primary healthcare services in South Africa could be researched.

People don't buy products. They buy expectations of benefit.

Roman \& Maas

\section{List of sources}

AFRICAN NATIONAL CONGRESS, 1994: The reconstruction and development programme (RDP). Johannesburg, SA: Umanyano Publications.

ANC. 1994: See African National Congress. 1994.

ANDREASON, AR 1995: Marketing social change: Changing behaviour to promote health, social development and the environment. San Francisco: JosseyBass.

BAXTER-DERRINGTON, P 1995: Marketing: Getting your message across. Nursing Standards. 9(41): 20-3.

BRENKERT, G 2002: Ethical challenges of social marketing. Journal of Public Policy and Marketing, 21(1): 14-25.

CALPIN-DAVIS, $\quad P$ 1998: A comprehensive business planning approach applied to health care. Nursing Standard. 12(46): 35-41.

\section{CENTER FOR REVIEWS AND} DISSEMINATIONS (CRD) PUBLICATIONS OFFICE, 2001: Undertaking systematic reviews of research on effectiveness. CRD Report, Number 4. $2^{\text {nd }}$ edition. Available: http:// www.york.ac.uk/inst/crd/report4.htm [Accessed: September 2002].

\section{COLLINSON, S \& COWLEY, S 1998:}

An explanatory study of demand for the health visiting service within a marketing framework. Journal of Advanced Nursing. 28(3): 499-507.

CRD PUBLICATIONS OFFICE, 2001: 
See Center for Reviews and Disseminations (CRD) Publications Office. 2001.

CRESWELL, WJ 1994: Research design. Qualitative and quantitative approaches. London: Sage.

DANA, K \& WOODS, BA 2002: Realizing your marketing influence. Part 1: Meeting patient needs through collaboration. Journal of Nursing Administration. 32(4): 325.

DENNILL, K; KING,L \& SWANEPOEI, T 1999: Aspects of primary health care: Community health care in Southern Africa. $2^{\text {nd }}$ edition. Cape Town: Oxford University Press.

DE VOS, AS; STRYDOM, H; FOUCHE, DB; POGGENPOEL, M; SHURINK.E\& SHURINK, W 1998: Research at grass roots. Pretoria: Van Schaik.

DIENEMANN, AJ 1998: Nursing administration: Managing patient care. $2^{\text {nd }}$ edition. USA: Appleton \& Lange.

HILLESTAI),SG \& BERKOWITZ,EN 1991: Health care marketing plans - From strategy to action. $2^{\text {nd }}$ edition. USA: Aspen Publication.

KOTLER, P; ROBERTO, N \& LEE, N 2002: Social marketing: Improving the quality of life. $2^{\text {nd }}$ edition. London: Sage.

KREFTING, L 1991: Rigor in qualitative research: The assessment of trustworthiness. American Journal of Occupational Therapy. 45(3): 214-22.

LIVESEY, H 1998: Fund-holding and contracting for community nursing services: A selective review of the literature. Journal of Advanced Nursing. 28(3): 483-90.

Mcdermott, B 1996: Marketing nursing. Nursing Standard. 10(20), February: 4956

NORTON, L 1998: Health promotion and health education: What role should the nurse adopt in practice? Journal of Advanced Nursing. 28(6): 1269-75.

PERREAULT, WD \& MCCARTHY, EJ 2002: Basic marketing: A global managerial approach. New York: McGrawHill.
PINE, BJ \& GILMORE, JH 2001: Welcome to the experience economy. Health Forum Journal. 44(5): 10-6.

POLIT, DF \& HUNGLER, BP 1997: Essentials of nursing research: Methods, appraisal and utilization. $4^{\text {th }}$ edition. Philadelphia: Lippincott-Raven.

SCHURINK, W 1996: Paper on qualitative data analysis. Pretoria: Human Sciences Research Council.

SOUBA, WW; HALUCK, CA \& MENEZES, MAJ 2001: Marketing strategy: An essential component of business development for academic health centers. The American Journal of Surgery, 181(2): 105-14.

THOMAS, RK 2002: Building on first impressions. Marketing Health Services, 22(2): $34-8$.

VAN RENSBURG, HCJ; FOURIE, A \& PRETORIUS, E 1992: Gesondheidsorg in Suid-Afrika: Struktuur en dinamika. Pretoria: Van Schaik.

VAN WYK, NC 1999: Health education as education of the oppressed. Curationis. 22(4): 29-34

WEISS, R 2002: Tales from the market front. Marketing Health Services. 22(2): 12-3.

WHITEHEAD, D 2000: Using mass media within health promoting practice: A nursing perspective. Journal of Advanced Nursing. 32(4): 807-16. 